\title{
17- B1 Türkçe ders kitaplarındaki kavram alanları ve kavram sayıları ${ }^{1}$
}

\section{Gökhan ARI ${ }^{2}$ \\ Eşref KAYMAK 3}

\begin{abstract}
APA: Arı, G.; Kaymak, E. (2021). B1 Türkçe ders kitaplarındaki kavram alanları ve kavram sayıları. RumeliDE Dil ve Edebiyat Araşturmaları Dergisi, (Ö10), 296-307. DOI: 10.29000/rumelide.1011423.
\end{abstract}

\section{$\ddot{O} \mathbf{z}$}

Türkçeyi yabancı dil olarak öğrenenler için hazırlanan ders kitaplarında öğrenicilerin maruz kaldıkları kelime ve kavramlar onların Türkçeyi öğrenmesinde ve kelime hazinelerini geliştirmesinde önem arz etmektedir. Bu çalışmanın amacı yabancı dil olarak Türkçe öğretiminde kullanılan iki kitaptaki metinleri inceleyerek kavram sayılarını, ulamları ve kavram alanlarını ortaya koymaktır. İncelenen kitaplar ise Altay Türkçe Öğreniyorum B1 ve Türkçeye Yolculuk B1 ders kitaplarıdır. Nitel araştırma desenine uygun şekilde desenlenen bu araştırma bir durum çalışmasıdır. Çalışmanın verileri doküman incelemesi yöntemi ile elde edilmiş, içerik analizi ile çözümlenmiştir. Ders kitaplarındaki metinler dijital ortama aktarıldıktan sonra MAXQDA 2018.2 kullanılarak kavram alanları, ulamlar ve kavramlar sınıflandırılmıştır. Sınıflandırma yapılırken ön tür kuramından yararlanılmıştır. Kavramların sınıflandırılması sonucunda Altay Türkçe Öğreniyorum B1 ders kitabında 29 kavram alanı, 155 ulam ve 1812 kavram; Türkçeye Yolculuk B1 ders kitabında 29 kavram alanı, 144 ulam ve 1665 kavram tespit edilmiştir. Tespit edilen kavram alanları ise şunlardır: Hayvanlar, eğitim, oluş, bitki, oyun, dil, durum, ulaşım, enerji, yer, vücut, yiyecek, duygular, sağlık, duyu, doğa, ediş, iletişim, kültür, sanat, meslek, eşya, insan, nicelik, konum, parça, zaman, biliş, niteliktir. Herhangi bir kavram alanı içerisinde yer almayan kavramlar ise diğer olarak adlandırılmıştır. Araştırma sonucunda her iki kitapta yer alan kavram sayıları, ulamlar ve kavram alanları görece yeterli bulunmuştur. Çalışmanın sonucunda ulaşılan veriler dikkate alınarak önerilerde bulunulmuştur.

Anahtar kelimeler: Ön- tür kuramı, kavram, kavram alanları, kavram sayısı

\section{Conceptual fields and lexical concept counts in B1- level Turkish coursebooks}

\begin{abstract}
In textbooks prepared for those who learn Turkish as a foreign language, the words and concepts that learners are exposed to are important for them to learn Turkish and improve their vocabulary. The purpose of this study is to reveal the concept numbers, categories and concept areas by examining the texts in two books used in teaching Turkish as a foreign language. The reviewed books are I'm Learning Altaic Turkish B1 and A Journey to Turkish B1 textbooks. This research, which is designed in accordance with the qualitative research pattern, is a case study. The data of the study were
\end{abstract}

1 Bu çalışma B1 Türkçe Ders Kitaplarında Kavramlar ve Kavram Alanları adlı yüksek lisans tezinin bir bölümünden geliştirilerek üretilmiştir.

Prof. Dr., Bursa Uludağ Üniversitesi, Eğitim Fakültesi, Türkçe Eğitimi, Türkçe ve Sosyal Bilimler Eğitimi Bölümü, Türkçe Eğitimi ABD (Bursa, Türkiye). gokhanari@uludag.edu.tr, ORCID: 000o-o001-7054-2209 [Araştırma makalesi, Makale kaylt tarihi: 27.09.2021-kabul tarihi: 20.10.2021; DOI: 10.29000/rumelide.1011423]

3 Türkçe Öğretmeni, Millî Eğitim Bakanlığı (Bursa, Türkiye). esref_kaymak@windowslive.com, ORCID ID: 0ooo-ooo31292-3382

$$
\begin{array}{r}
\text { Adres } \\
\text { RumeliDE Dil ve Edebiyat Araştırmaları Dergisi } \\
\text { Osmanağa Mahallesi, Mürver Çiçeği Sokak, No:14/8 } \\
\text { Kadıköy - İSTANBUL / TÜRKIYE 34714 } \\
\text { e-posta: editor@rumelide.com } \\
\text { tel: +90 505 7958124, +90 } 2167730616
\end{array}
$$

Address

RumeliDE Journal of Language and Literature Studies Osmanağa Mahallesi, Mürver Çiçeği Sokak, No:14/8

Kadıköy - ISTANBUL / TURKEY 34714

e-mail: editor@rumelide.com,

phone: +90 5057958124 , +90 2167730616 
obtained by document review method and analysed by content analysis. After the texts in the textbooks were digitized, Using MAXQDA 2018.2, concept areas, categories and concepts were classified. As a result of the classification of the concepts, it is found out that I Am Learning Altaic Turkish B1 textbook has 29 concept areas, 155 categories and 1812 concepts; A Journey to Turkish B1 textbook has 29 concept areas, 144 categories and 1665 concepts. The identified areas of concept are: animals, education, being, plant, game, language, situation, transportation, energy, place, body, food, emotions, health, sense, nature, make, communication, culture, art, profession, item, person, quantity, location, part, time, cognition, quality. Concepts that are not included in any concept field have been called other concepts. As a result of the research, the concept numbers, categories and concept fields contained in both books have been found to be relatively sufficient. At the end of the study, taking into account the data obtained, certain recommendations were made.

Keywords: Pre-type theory, concept, concept fields, concept counts

\section{Giriş}

İnsanlar kavramları şartlanma, aktarma, bağlam, genelleme, belirginleştirme, ayırt etme, sınıflandırma (Arı, 2014) ve soyutlama (Karadağ, 2013) yollarıyla edinir veya öğrenirler. Edinim veya öğrenme yaşantı yoluyla kendiliğinden olabileceği gibi eğitim süreci içerisinde çeşitli bağlamlarla sistematik bir biçimde de gerçekleşebilir. Aslında hedef dili öğrenen kişinin zihninde kavramlar vardır. Öğrenici, hedef dildeki kelimeyi zihnindeki kavramlara transfer eder.

Kelime öğretimi bir dili öğrenmenin temelini oluşturmaktadır. Kelime öğretiminin daha planlı ve nitelikli olabilmesi için kavramlarla ilişkilendirilmesi gerekir. Kavramlar arasında ilişki kurarak aynı kavram alanına dahil olan kelimelerle kelime öğretimi daha hızlı yapılabilir. Çünkü kavramlar kelimelerle ifade edilir (Ülgen, 2004). Yabancı dil olarak Türkçe öğretimi ders kitaplarındaki kavramların ortaya konarak bu çerçevede kelime öğretiminin planlanması, kelime öğretimi sürecini daha etkin hâle getirebilir. Bunu sağlamanın yollarından biri kavram alanlarına (üst düzey kavram/tema) ait ulamların (temel düzey kavram/kategori) ve kavramların (alt düzey kavram) ortaya konmasıdır. Örneğin eşya kavram alanında oturma eşyası ile ilgili ulamlara ait kelimeler şunlar olabilir: oturak, tabure, iskemle, sandalye, koltuk, kanepe, bank, çekyat vb. Kelime öğretiminde bu eşya kavramlarını vererek bunlar arasındaki ilişkiyi öğrenicinin farkında olmasını sağlayıcı etkinlikler yapmak gerekir. Oturak oturma eşyalarının genel adı olmakla birlikte alçak iskemle yerine de geçmektedir. Sırt dayama yeri olmayan oturma aracına ise tabure veya iskemle denilmektedir. Sandalyede sırt dayama bölümü varken kol dayama bölümü yoktur. Koltuk ise sirt ve kol dayama bölümü olan ve sandalyeye göre geniş ve konforlu bir oturma aracıdır. Kanepe koltuğun çoklu biçimidir. Çekyat ise hem çoklu koltuk hem de yatak olabilen bir araçtır. Kanepe ve çekyat ev eşyasıdır, kanepeye benzeyen sıra eğitim ortamında, bank ise dış ortam oturma eşyasıdır. Kanepeye ve çekyata hem yatılır hem oturulur. Bu ilişkiler verildiğinde $\mathrm{B} 1$ öğrenicisinin hem kelime hazinesi genişletilmiş hem de kavram üzerinden kelime öğretimi çeşitlendirilmiş olur. Böylece az zamanda birden fazla kavram ve kelime öğretilmiş olur. Yabancı dil olarak Türkçenin öğretiminde, ders işleme sürecinde yukarıda örneklediğimiz bir kelime öğretimi yapılabilmesi için kelimeler; kavramlar ve kavram alanlarıyla bağlantı kurularak öğretilmelidir. Bu ilişkileri daha somut anlatabilmek için kavramlar, kavram alanlarına ulaşabilmek için kavram sınıflandırmasıyla ilgili teorik bilgiler vermek yararlı olacaktır.

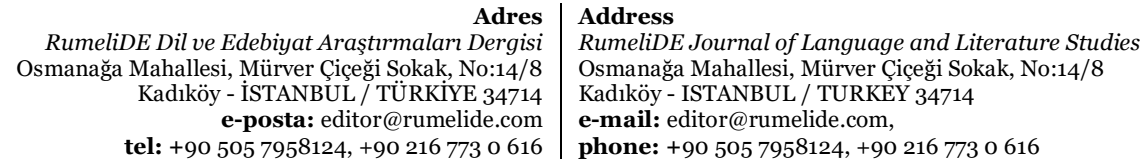




\section{Kavramlar ve kavramların sınıflandırılması}

Bilindiği üzere dildeki kelimeler, dil dışı dünyadaki nesne ve varlıkları temsil eder. Varlıkların ve kelimelerin zihindeki tasarımı ise kavramdır (Akyürek, 2003; Cevizci, 1999; Gunina, 2011; Ülgen, 2001).

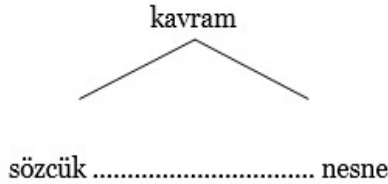

Şekil 1. Kavram-kelime-nesne ilişkisi (Koç, 1996, s. 151)

Şekil 1'de dildeki nedensizlik ilkesi gereği kelime ile varlık/nesne arasında dolaylı, kavramın kelime ve varlık/nesne ile doğrudan bağlantılı olduğu görülmektedir (Koç, 1996). Dolayısıyla kelimenin anlamını ortaya koyan kavram, kelimenin kendi anlamından daha geniştir (Onan, 2011). Bu genişlik sebebiyle kişinin zihninde karmaşık hâlde bulunan kelime ve kavramlar bilgiye ihtiyaç duyulduğunda işe koşulabilir. Bunu karmaşıklıktan kurtarmak için sınıflandırılmış kavramlar üzerinde art alan bilgisi olarak çalışmaya gereksinim vardır. Çünkü kavramlar belirli özellikleri dikkate alınarak sınıflara ayrlırlar. Bunun sonucunda karmaşık durumlar daha basit bir şekilde söz varlığına aktarılır (Eken, 2015). Bu sınıflamanın farklı yolları bulunmaktadır. Borghi, Caramelli ve Setti, (2005) geleneksel olarak üst düzey (hayvan), temel düzey (köpek), alt düzey (tazı) ilişki sayesinde kavramların sınıflandığını varsaymışlardır. Çalışmamızda temelde buna benzer bir sınıflama mantığı kullandığımızı belirtmeliyiz.

Kavramların nasıl sınıflandırılması gerektiğiyle ilgili farklı görüşler bulunmaktadır. Bunlardan biri ön tür kuramıdır. Ön tür kuramında merkezde bir prototip bulunmaktadır. Bu ilgili türü en güçlü şekilde temsil ettiği varsayılan varlıktır. Diğer üyelerin aile benzerliği ilişkileri, prototip ile ortak özellikleri, ayrıldıkları noktaları, ilgili ulamı temsil kabiliyeti ilgili ulamın iç yapısı ile ilgilidir ve yatay düzeyde ele alınmaktadır. Ulamların kendi aralarındaki ilişki ise dikey düzeyde ele alınmaktadır. Bunlar: Alt düzey, temel düzey ve üst düzeydir. Örneğin yer, bina, iş yeri gibi kavramların sırasıyla üst düzey, temel düzey ve alt düzeyi yansıtmaktadır. Temel düzey, alt ve üst düzeye göre daha hılı kategorize edildikleri gibi genel bilgimizin de çoğunun organize edildiği seviye olmaktadır (Löbner, 2002). Bu yüzden temel düzey kavramların en kolay öğrenilen, çabuk ayırt edilebilen kavramlar olması beklenir. Croft ve Cruse'a (2004) göre üst düzey ulamların belirgin özelikleri daha azdır (akt. Coşkun, 2006). Bu yüzden daha genel bir kategori seviyesini oluşturmaktadırlar. Alt düzey kategori içerisine giren kavramlar; temel ve üst düzey kategorilere göre çok daha fazla özelliklere sahiptir ve deneklerin alt düzey kavramları kategorize ederken daha yavaş tepki verdikleri ayrıca uzun zaman harcadıkları bilinmektedir (Çengelci, 1996). Alt düzey kategori içerisindeki kavramlar daha özelleşmiş, kendi aralarında yüksek benzerlik taşıyan kavramlardır.

Rosch'un 1973'teki çalışmasındaki bulgulara göre deneklere verilen kavramları en tipikten en zayıfa doğru puanlaması istendiğinde aşağıdaki tabloda verilen kavramlar ve puanlar ortaya çıkmıştır.

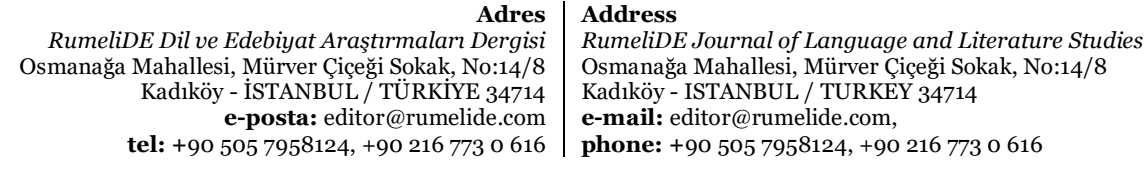


Tablo 1. Rosch'un 1973'te elde ettiği en tipik üye dereceler (Rosch’tan akt. Pesonen, 2002, s. 19)

\begin{tabular}{llllll}
\hline Meyve & \multicolumn{3}{l}{ Sebze } & Kuş & \\
\hline elma & 1.3 & havuç & 1.1 & kızılgergedan & 1.1 \\
erik & 2.3 & kuşkonmaz & 1.3 & kartal & 1.2 \\
çilek & 2.3 & soğan & 2.7 & devekuşu & 3.3 \\
incir & 4.7 & maydanoz & 3.8 & tavuk & 3.8 \\
zeytin & 6.2 & salatalı & & yarasa & 5.8 \\
\hline Taşıt & & Hastalık & & Suç & \\
\hline araba & 1.0 & kanser & 1.2 & cinayet & 1.0 \\
scooter & 2.5 & sitma & 1.4 & hirsızlık & 1.3 \\
üç t. bisiklet & 3.5 & kızamık & 2.8 & şantaj & 1.7 \\
kayak & 5.7 & romatizma & 3.5 & zim.para geç. & 1.8 \\
at & 5.9 & nezle & 4.7 & serserilik & 5.3 \\
\hline
\end{tabular}

Tablo 1'de, 1 den 7'ye kadar verilen puanların açıklaması ise şöyledir: 1 en tipik üye, 7 ise en zayı üye konumundadır. Bu puanlamaya göre ulamları en iyi temsil eden üyeler içerisinde en yüksek orana sahip olan üye şunlardır: Taşıt ulamında, araba (1.o); suç ulamında cinayet (1.o) ögesidir. En az (zayıf) üye ise meyve ulamında zeytin (6.2) ögesi olmuştur. Bu sınıflama, kavramların bağlantısını ve hiyerarşini göstermektedir.

Kavramların sınıflandırması ile ilgili önemli bir sınıflama da Clark'a aittir. Clark'ın (1973) anlambilimsel özellik varsayımına dayanan sınıflandırması Tablo 2'de gösterilmiştir:

Tablo 2. Clark (2003)'ın ad, eylem ve sıfat ulamlarına ilişkin sınıflaması (akt. Eken, 2015, s. 396)

\begin{tabular}{lll}
\hline Ulam & Alt Ulam & Örnek \\
\hline & insan & bebek, adam, anne, kız, oğlan \\
& hayvan & kedi, köpek, tavşan, fare \\
& araç & araba, kamyon, tren, bisiklet \\
& vücut Bölümü & burun, göz, baş, parmak, el, diz \\
Ad & giysi & bez, çorap, tişört \\
& oyuncak & top, bebek, lego \\
& mobilya & sandalye, masa, yatak, banyo \\
& ev eşyaları & telefon, ş̧ı, çaydanlı, saat \\
& yiyecek & süt, meyve suyu, peynir \\
& yiyecek- içecek kalıbı & şişe, bardak, kaşı, tabak \\
\hline Sifat & özellik- durum & sicak, soğuk, islak \\
\hline Eylem & edimsellik & git-, koy-, yap-, \\
\hline
\end{tabular}

Tablo 2'ye göre Clark ulamları ad, sıfat ve eylem olarak 3'e ayırmış ve bu ulamları da 12 alt ulama ayırarak karşılarına örneklerini yazmıştır. Ad ulamında 10, sıfat ve eylem ulamlarında birer alt ulam ortaya konmuştur. Örnek olarak verilen sınıflamaların, kelime ve kavram öğretimine yol gösterici bir nitelikte olduğu söylenebilir. Kavram sınıflamalarının yabancılara kelime öğretiminde kullanılabilmesi için benzer tasniflere ihtiyaç duyulmaktadır.

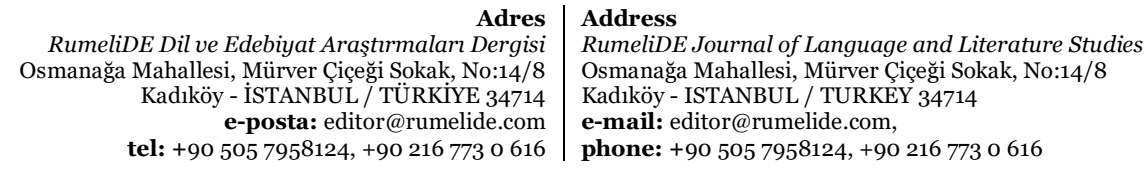


Yabancı dil olarak Türkçenin öğretimi, özellikle orta seviyeden (B1-B2) itibaren, metin temelli sürdürülmektedir. Temalar altında yer alan metinlerde hangi kavramların geçtiğini, bu kavramların birbiriyle ne tür ilişkiler kurduğunu (ulam) ve hangi kavram alanları oluşturduğunu belirlemek, böylece kelime ve kavram öğretiminin kesiştiği alanı ortaya çıkarmada bir fikir verebilmek; bu alanda hazırlanacak ders materyallerine katkı sunmayı sağlayabilir. Kavram alanlarına ait ulam ve kavramların neler olduğu, bunların hangi seviyelerde nasıl verileceği geniş kapsamlı çalışmalarla ortaya konabilir. Ancak gerek ana dili olarak gerekse yabancı dil olarak Türkçe öğretimi üzerine kavram veya kavram alanı çalışmalarının yetersiz olduğu görülmektedir. Var olan sınırlı çalışmalarda tespit edilen kavramlar genellikle yüzeysel biçimde bulgulanmış ve incelenen materyalden seçilmiş kavram alanları üzerine genel yorumlar yapılmıştır (örn. Aşık, 2020). Bir ders kitabında hangi kavramların geçtiği, bu kavramların o ders kitabında hangi kavramlarla ilişkilendirilebileceğini ortaya koyan bir çalışmaya rastlanmamıştır. Bu alanda yapılan çalışmalar incelendiğinde kelime öğretimi üzerine tezlerin yapıldığı ancak kavram alanı çalışmalarının çok sınırlı olduğu görülmektedir. Kelime ve kavram öğretimine bir bakış açısı getirebilmek, ders kitaplarında hangi kavram alanlarında hangi kavramların yabancılara sunulduğunu belirleyebilmek için kavramları sınıflandırmaya ihtiyaç duyulduğu görülmektedir.

$\mathrm{Bu}$ ihtiyacı karşılamaya dönük olarak araştırmanın amacı yabancı dil olarak Türkçe öğretiminde kullanılan iki kitaptaki metinleri inceleyerek kavram sayılarını ve kavram alanlarını ortaya koymaktır.

\section{Yöntem}

Araştırma, nitel araştırma desenlerinden durum çalışmasına uygun şekilde tasarlanmıştır. "Bir durum çalışması, özellikle bir olgu ve bağlam arasındaki sınırların açık olmadığı durumlarda, çağdaş bir olguyu derinlemesine ve gerçek yaşam bağlamında inceleyen gözlemci bir araştırmadır” (Yin, 2009, s.18). Bu çalışmada kitaplardaki metinlerde geçen kelimeler ve kavram arasındaki sınırlar ortaya konmaya çalışılmış, öğretimde kullanıldığı varsayılan metinlerdeki kelimeler bu doğrultuda sınıflanmıştır.

\section{Veri kaynakları}

Araştırmada incelenen kitaplar Türkçe Altay Türkçe Öğreniyorum ve Türkçeye Yolculuk B1 ders kitaplarıdır. Altay Türkçe Öğreniyorum B1 ders kitabı 168 sayfadan oluşmaktadır. Kitabın içerisinde 8 ünite, 8 konu adı ve 40 okuma metni yer almaktadır. Türkçeye Yolculuk B1 ders kitabı 200 sayfadan oluşmaktadır. Kitabın içerisinde 8 ünite, 16 konu adı ve 41 okuma metni yer almaktadır. Çalışmaya metin sonu etkinlikleri dahil edilmemiştir.

\section{Verilerin toplanması ve çözümlenmesi}

Çalışmada verilerin toplanması doküman analizi ile gerçekleştirilmiştir. Verilerin toplanma aşamasında büyük ölçüde ön tür yaklaşımındaki sınıflandırma anlayışından yararlanılmıştır. Veri toplamada şu işlemler gerçekleştirilmiştir. İlk olarak okuma metinleri manuel olarak MS Word programına aktarılmıştır. Kitaplardaki resimler ve şekiller ayıklanmış, etkinlikler çalışmaya dahil edilmemiştir. Metinleri oluşturan kelimeler tek tek kontrol edilerek gözden geçirilmiştir. Sonrasında iki kitabın ilk ünitelerini oluşturan metinlerdeki kavramlar sınıflandırılmıştır. Uzman görüşü alınarak sınıflandırmadaki birtakım sorunlar giderilmiştir. Okuma metinlerinde geçen özel isimler, soru kelimeleri, sayılar, kalıp ifadeler, birleşik yapıdaki fiillerdeki isimler, zarf-fiiller, sıfat-fiiller ve yüklem olan fiiller çalışmaya dahil edilmemiştir.

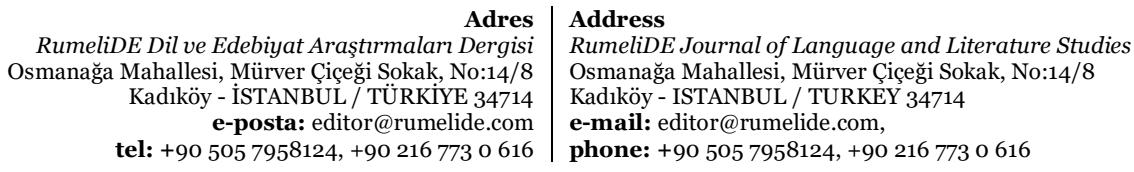


Çalışmada veri çözümleme yöntemi olarak içerik analizi kullanılmıştır. Kitaplarda geçen kelimelerin anlamı düşünülerek bağlamdaki duruma göre içerik analizi yapılmıştır Veriler elde edilirken kelimeler MS Word dosyasına aktarılmıs, her metin belge olarak MAXQDA 2018.2 programına eklenmiş, anlama ve bağlama uygun şekilde kavramlar kodlanmıştır. Kelime ve kelime grupları kodlanarak hangi kavramsal kategorilere ait olduğu bu yolla belirlenmiştir. Yani kavramlardan (kod) ulamlara (kategori) ve ulamlardan kavram alanlarına (tema) ulaşılmıştır.

Çalışmanın nihai bulgularına geçmeden önce yukarıda anlatılan sınıflandırmanın nasıl gerçekleştiğini somutlamak için sanat kavram alanındaki ulam ve kavramların görünümü Tablo 3’te sunulmuştur.

Tablo 3. Sanat kavram alanı

\begin{tabular}{|c|c|c|}
\hline Ulamlar & $\begin{array}{l}\text { Türkçeye Yolculuk B1 } \\
\text { Kavramlar ve kavram sıklığı }\end{array}$ & $\begin{array}{l}\text { Altay Türkçe Öğreniyorum B1 } \\
\text { Kavramlar ve kavram sıklığı }\end{array}$ \\
\hline Hareket Sanatları (12- 2) & $\begin{array}{l}\text { perde (7), gölge oyunu (5), tiyatro } \\
\text { (3), tip (2), kukla (1), Hacivat (1), } \\
\text { ağabey rolü (1), başrol (1), dans (1), } \\
\text { gölge hayal (1), ş̧lk (1), Karagöz (1) }\end{array}$ & dans (1), halk oyunu (1) \\
\hline Dokuma Sanatı (o- 2) & - & $\begin{array}{l}\text { dokuma sanatı (2), halı dokuma } \\
\text { sanatı (2) }\end{array}$ \\
\hline Hacim Sanatları (o- 3) & - & $\begin{array}{l}\text { heykel (6), dinozor heykeli (1), } \\
\text { seramik sanatı (1) }\end{array}$ \\
\hline Yüzey Sanatları (2- 21) & fotoğraf (5), kamera görüntüsü (1) & $\begin{array}{l}\text { fotoğraf (18), desen (7), resim (9), } \\
\text { çini (3), telkari (3),ebru (3), çini } \\
\text { sanatı (2), göz deseni (2), tablo (2), } \\
\text { süsleme sanatı (2), resim (2), altın } \\
\text { işleme sanatı (1), boya (1), boyama } \\
\text { (1), ebru sanatı (1), gümüş işleme } \\
\text { sanatı (1), motif (1), oto portre (1), } \\
\text { resim çizme (1), resim yapma } \\
\text { (1), resim yeteneği (1) }\end{array}$ \\
\hline
\end{tabular}

Ses Sanatları (o- 28)

Dramatik Sanatlar (16- 11) film (22), oyun (5), rol (4), sinema (2), dizi (1), dram filmi (1), dramatik belgesel (1), gala (1), kısa film (1), orta oyunu (1), sinema dünyası (1), sinema filmi (1), sohbet programı (1), tanitım filmi (1), tanitım videosu (1), televizyon (program) (1) müzik (10), albüm (6), eser (4), konser (4), davul (3), armoni (2), piyano (3), saray (3), turne (2), zurna (2), kapanış konseri (1), barok (1), beste yapma (1), çalma (1), halay (1), horon (1), kemençe (1), kilise (1), klasik (1), klasik müzik (1), konservatuar (1), müzik aleti (1),müzik bilimi (1), müzik enstrümanı (1), rap müzik (1), şarkı (1), tulum (1), zeybek (1)

film (11), dizi (8), çizgi film (2), başrol (1), başrol oyunculuğu (1), drama (1), karakter (1), komedi (1), kukla (1), sinema filmi (1), video (1)

Adres | Address

RumeliDE Journal of Language and Literature Studies

Osmanağa Mahallesi, Mürver Çiçeği Sokak, No:14/8

Kadıköy - ISTANBUL / TURKEY 34714

e-mail: editor@rumelide.com,

tel: +90 505 7958124, +90 2167730616 phone: +90 505 7958124, +90 2167730616 
Dil Sanatları (17- 7)

Sanat Akımları (o- 8)

Diğer (4-7) edebiyat (6), roman (6), senaryo (5), hikâye (4), şiir (4), uzun hikâye (2), metin (2), resim (2), atasözü (1), bilmece (1), gülünç hikâye (1), masal (1), otobiyografik (1), psikolojik roman (1), resim sanatı (1), şarkı (1), yazı hayatı (1) masal (12), türkü (2), günlük (2), anı (1), hikâye (1), mani (1), şarkı (1) kübist (2), barok dönem (1), klasik kültür (1), kübist eser (1), mavi dönem (1), pembe dönem (1), romantik dönem (1), romantizm

(1) sanat (6), eser (2), baskı (1), güzel sanatlar (2) sanat (8), eser (7), geleneksel sanat (1), güzel sanatlar (1), sanat dalı (1), dekorasyon (1), tarihi eser (1)

Toplam

51 kavram

88 kavram

Tablo 3 incelendiğinde Türkçeye Yolculuk ders kitabında 4 ulam 51 kavram; Altay Türkçe Öğreniyorum ders kitabında 8 ulam, 89 kavram ortaya çıtı̆̆̆ görülmektedir.

Tablo 3'e bakıldığında Türkçeye Yolculuk ders kitabında en fazla kavrama sahip olan ulam, dil sanatları (17) ulamıyken; Altay Türkçe Öğreniyorum ders kitabında ses sanatları (28) ulamı en fazla kavrama sahip ulamlardır.

Tablo 3'e göre Türkçeye Yolculuk ders kitabında en az kavrama sahip olan ulam dokuma sanatları, hacim sanatları, ses sanatları ve sanat akımları (o) ulamlarıyken; Altay Türkçe Öğreniyorum ders kitabında hareket sanatları ve dokuma sanatları (2) ulamları en az kavrama sahip ulamlardır. Çalışmanın anlaşılabilmesi için Tablo 3’teki bulgular ile Tablo 4’teki “sanat” kavram alanı karşılaştırılabilir.

Sınıflandırmanın tamamı, sanat temasındaki gibi gösterilemeyeceğinden Bulgular başlığı altında sadece sınıflandırma ile ulaşılan kavram alanlarına, ulamlara ve kavram sayılarına yer verilmiştir.

\section{Bulgular}

Bu bölümde ulaşılan kavram alanları, ulamlar ve kavram sayıları Tablo 4’te iki kitap için iki ayrı sütunda gösterilmiştir.

Tablo 4. Altay Türkçe Öğreniyorum ve Türkçeye Yolculuk B1 Ders Kitaplarındaki Okuma Metinlerinde Yer Alan Kavram Alanları, Ulamlar ve Kavram Sayıları

\begin{tabular}{|c|c|c|c|}
\hline & \multicolumn{2}{|l|}{ Türkçeye Yolculuk B1 } & Altay Türkçe B1 \\
\hline $\begin{array}{l}\text { Kavram } \\
\text { alanı/Ulam } \\
\text { Sayısı }\end{array}$ & \multicolumn{2}{|l|}{ Ulamlar ve Kavram sayıları } & Ulamlar ve Kavram sayıları \\
\hline Eşya (13-11) & \multicolumn{2}{|c|}{$\begin{array}{l}\text { teknolojik aletler (22), kırtasiye (2), silah } \\
(2), \text { para (6), hirdavat (5), iletişim (3), } \\
\text { kimyasal (10), taşıma eşyaları (7), takı- } \\
\text { aksesuar (1), ev eşyaları (32), kıyafet (9), } \\
\text { belge- kitap (26), diğer (16) }\end{array}$} & $\begin{array}{l}\text { teknolojik aletler (43), kirtasiye (2), para (1), } \\
\text { hirdavat (15), iletişim (8), takı-aksesuar (14), } \\
\text { kimyasal (2), ev eşyaları (19), kıyafet (10), } \\
\text { belge- kitap(9), diğer (12) }\end{array}$ \\
\hline & $\begin{array}{r}\text { Adres } \\
\text { RumeliDE Dil ve Edebiyat Arasstırmaları Dergisi } \\
\text { Osmanağa Mahallesi, Mürver Chiçeği Sokak, No:14/8 } \\
\text { Kadıköy - İSTANBUL / TÜRKIYE } 34714 \\
\text { e-posta: editor@rumelide.com } \\
\text { tel: +90 505 7958124, +90 216 773 o } 616\end{array}$ & $\begin{array}{l}\text { Addr } \\
\text { Rume } \\
\text { Osma } \\
\text { Kadil } \\
\text { e-ma } \\
\text { phor }\end{array}$ & $\begin{array}{l}\text { Journal of Language and Literature Studies } \\
\text { Mahallesi, Mürver Çiçeği Sokak, No:14/8 } \\
\text { ISTANBUL / TURKEY } 34714 \\
\text { ditor@rumelide.com, } \\
90 \text { 505 7958124, +90 } 216773 \text { o } 616\end{array}$ \\
\hline
\end{tabular}




\begin{tabular}{|c|c|c|}
\hline & Toplam: 141 kavram & Toplam: 135 kavram \\
\hline \multirow[t]{2}{*}{ Hayvan (2- 2) } & kara hayvanları (10), deniz hayvanları (1) & kara hayvanları (9), deniz hayvanları (1) \\
\hline & Toplam: 11 kavram & Toplam: 10 kavram \\
\hline \multirow[t]{2}{*}{ Eğitim (2- 4) } & $\begin{array}{l}\text { öğrenme- öğretme (2), ölçme değerlendirme } \\
\text { (3) }\end{array}$ & $\begin{array}{l}\text { Öğrenme- Ö̆gretme (6), ölçme } \\
\text { değerlendirme (5), eğitim türleri (14), diğer } \\
\text { (2) }\end{array}$ \\
\hline & Toplam: 5 kavram & Toplam: 27 kavram \\
\hline \multirow[t]{2}{*}{ Oluş (1- 1) } & hava (6) & hava (4) \\
\hline & Toplam: 6 kavram & Toplam: 6 kavram \\
\hline \multirow[t]{2}{*}{ Bitki (1- 4) } & çiçekli bitkiler (2) & $\begin{array}{l}\text { çiçekli bitkiler (5), çiçeksiz bitkiler (1), } \\
\text { bitkilerin bölümleri (4), diğer (1) }\end{array}$ \\
\hline & Toplam: 2 kavram & Toplam: 11 kavram \\
\hline \multirow[t]{2}{*}{ Oyun (5- 5) } & $\begin{array}{l}\text { spor eğitimi (2), spor kuruluşları (1), takım } \\
\text { sporları (8), bireysel sporlar (9), diğer (2) }\end{array}$ & $\begin{array}{l}\text { oyunlar ile ilgili terimler (19), spor } \\
\text { kuruluşları (4), takım sporları (3), oyuncak } \\
\text { araç- gereçleri (11), diğer (1) }\end{array}$ \\
\hline & Toplam: 22 kavram & Toplam: 37 kavram \\
\hline \multirow[t]{2}{*}{ Dil (5- 4) } & $\begin{array}{l}\text { dil birimleri (1), dil becerileri (2), yazı (7), } \\
\text { genel (1), diğer (2) }\end{array}$ & dil birimleri (1), yazı (12), genel (1), diğer (1) \\
\hline & Toplam: 13 kavram & Toplam: 15 kavram \\
\hline \multirow[t]{2}{*}{ Durum (4- 4) } & $\begin{array}{l}\text { duyu (3), zaman dilimi (3), ilişki (1), diğer } \\
\text { (19) }\end{array}$ & $\begin{array}{l}\text { duyu (3), zaman dilimi (4), ilişki (5), diğer } \\
\text { (21) }\end{array}$ \\
\hline & Toplam: 26 kavram & Toplam: 33 kavram \\
\hline \multirow[t]{2}{*}{ Ulaşım (2- 2) } & trafik (34), taşıt (12) & trafik (4), taşıt (11) \\
\hline & Toplam: 46 kavram & Toplam: 15 kavram \\
\hline \multirow[t]{2}{*}{ Enerji (2- 2) } & elektrik enerjisi (1), diğer (2) & kimyasal enerji (1), elektrik enerjisi (3) \\
\hline & Toplam: 3 kavram & Toplam: 4 kavram \\
\hline \multirow[t]{2}{*}{ Yer (14-15) } & $\begin{array}{l}\text { eğlence (2), yemek (3), sağlık kuruluşları } \\
\text { (1), ticari (7), doğal (5), idari birimler (9), } \\
\text { barınma (5), eğitim (6), belirsizlik (14), yapı } \\
\text { (11), adli (2), trafik (7), insan yapımı (6), } \\
\text { diğer (2) }\end{array}$ & $\begin{array}{l}\text { yemek (3), tarım (3), sağlık kuruluşları (1), } \\
\text { hayal ürünü (2), askeri (1), ticari (2), doğal } \\
\text { (7), idari birimler (13), spor alanı (10), } \\
\text { barınma (4), dini (2), eğitim (23), belirsizlik } \\
\text { (21), yapı (12), diğer (2) }\end{array}$ \\
\hline & Toplam: 80 kavram & Toplam: 106 kavram \\
\hline \multirow[t]{2}{*}{ Vücut (3- 3) } & iskelet sistemi (11), iç organlar (8), diğer (4) & iskelet sistemi (12), iç organlar (6), diğer (1) \\
\hline & Toplam: 23 kavram & Toplam: 19 kavram \\
\hline
\end{tabular}

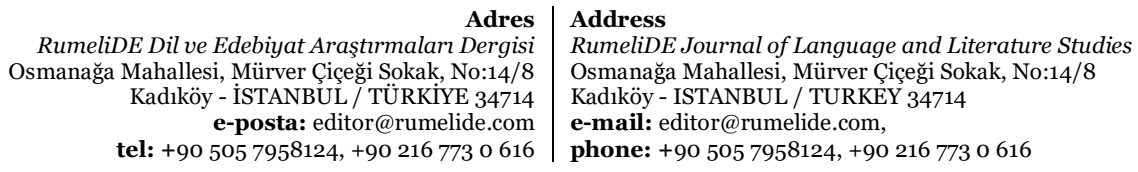




\begin{tabular}{|c|c|c|}
\hline \multirow[t]{2}{*}{$\begin{array}{l}\text { Yiyecek (12- } \\
\text { 11) }\end{array}$} & $\begin{array}{l}\text { zararlı içecekler (1), aperitif yiyecekler (2), } \\
\text { dünya mutfakları (1), tatll- meşrubat (2), } \\
\text { tahıl ürünleri (3), ögüun adları (4), besin } \\
\text { içerikleri (6), sebze (2), hayvansal gıdalar } \\
\text { (6), meyveler (8), sıvı gldalar (14), diğer (16) }\end{array}$ & $\begin{array}{l}\text { zararlı içecekler (2), dünya mutfakları (2), } \\
\text { tatlı- meşrubat (6), tahıl ürünleri (4), öğün } \\
\text { adları (1), besin içerikleri (18), sebze (5), } \\
\text { hayvansal gıdalar (5), meyveler (7), sıvı } \\
\text { gıdalar (6), diğer (8) }\end{array}$ \\
\hline & Toplam: 65 kavram & Toplam: 64 kavram \\
\hline \multirow[t]{2}{*}{$\begin{array}{l}\text { Duygular (3- } \\
\text { 4) }\end{array}$} & $\begin{array}{l}\text { olumlu duygular (7), olumsuz duygular (4), } \\
\text { duygu isimleri (7) }\end{array}$ & $\begin{array}{l}\text { olumlu duygular (9), olumsuz duygular (9), } \\
\text { duygu isimleri (7), diğer (1) }\end{array}$ \\
\hline & Toplam: 18 kavram & Toplam: 26 kavram \\
\hline \multirow[t]{2}{*}{ Sağlık (3- 3) } & $\begin{array}{l}\text { hastalık- rahatsızlık türü (15), tedavi (15), } \\
\text { diğer (3) }\end{array}$ & $\begin{array}{l}\text { hastalık- rahatsızlık türü (33), tedavi (11), } \\
\text { diğer (3) }\end{array}$ \\
\hline & Toplam: 33 kavram & Toplam: 46 kavram \\
\hline \multirow[t]{2}{*}{ Duyu (5- 5) } & $\begin{array}{l}\text { tatma (1), dokunma (2), koku (1), işitme (4), } \\
\text { görme (1) }\end{array}$ & $\begin{array}{l}\text { tatma (1), dokunma (1), koku (3), işitme (5), } \\
\text { görme (2) }\end{array}$ \\
\hline & Toplam: 9 kavram & Toplam: 12 kavram \\
\hline \multirow[t]{2}{*}{ Doğa (5- 6) } & $\begin{array}{l}\text { orman (1), deniz (1), kayaç (3), maden (4), } \\
\text { diğer (2) }\end{array}$ & $\begin{array}{l}\text { orman (1), deniz (1), } \operatorname{kayaç}(11), \text { maden (4), } \\
\text { gezegen ve etkileri (4), diğer (1) }\end{array}$ \\
\hline & Toplam: 11 kavram & Toplam: 22 kavram \\
\hline \multirow[t]{2}{*}{ Ediş (4- 4) } & et- /ol - (16), -1ş (16), -1m (23), -ma (155) & et- /ol- (16), -1ş (5), -1m (24), -ma (96) \\
\hline & Toplam: 210 kavram & Toplam: 141 kavram \\
\hline \multirow[t]{2}{*}{ İletişim (5- 6) } & $\begin{array}{l}\text { yazılı (16), dijital (9), sözlü (9), işarete } \\
\text { dayalı (7), diğer (3) }\end{array}$ & $\begin{array}{l}\text { yazılı (8), dijital (11), sözlü (7), işarete dayalı } \\
\text { (11), iletişim ögeleri (12), diğer (5) }\end{array}$ \\
\hline & Toplam: 44 kavram & Toplam: 54 kavram \\
\hline \multirow[t]{2}{*}{ Sanat (5-9) } & $\begin{array}{l}\text { hareket sanatları (12), yüzey sanatları (2), } \\
\text { dramatik sanatlar (16), dil sanatları (17), } \\
\text { diğer (4) }\end{array}$ & $\begin{array}{l}\text { hareket sanatları (2), dokuma sanatı (2), } \\
\text { hacim sanatları (3), yüzey sanatları (21), ses } \\
\text { sanatları (28), dramatik sanatlar (11), dil } \\
\text { sanatları (7), sanat akımları (8), diğer (7) }\end{array}$ \\
\hline & Toplam: 51 kavram & Toplam: 88 kavram \\
\hline \multirow[t]{2}{*}{ Kültür (2- 3) } & iş kültürü (6), diğer (6) & $\begin{array}{l}\text { dinsel ögeler (12), dügüun- şenlik (27), diğer } \\
\text { (7) }\end{array}$ \\
\hline & Toplam: 12 kavram & Toplam: 46 kavram \\
\hline \multirow[t]{2}{*}{$\begin{array}{l}\text { Meslek (11- } \\
\text { 10) }\end{array}$} & $\begin{array}{l}\text { yönetici (18), kültür- sanat (8), meslek } \\
\text { adları (8), akademik yönlü meslekler (6), } \\
\text { emek (5), esnaf- ticaret (4), tıp (2), hukuk } \\
\text { (2), kolluk kuvvetleri (4), tarım- } \\
\text { hayvancılık- avcılık (3), diğer (5) }\end{array}$ & $\begin{array}{l}\text { yönetici (5), kültür -sanat (16), meslek adları } \\
\text { (13), eğitim- öğretim (6), spor (3), akademik } \\
\text { yönlü meslekler (12), emek (6), esnaf- ticaret } \\
\text { (6), tıp (1), diğer (16) }\end{array}$ \\
\hline & Toplam: 65 kavram & Toplam: 84 kavram \\
\hline \multirow[t]{2}{*}{ İnsan (9- 8) } & $\begin{array}{l}\text { aile (15), sosyal ilişkiler (10), cinsiyet (7), } \\
\text { topluluk (8), hastalığa dayalı (4), gelişim } \\
\text { dönemi (4), eğitim- öğretim (3), trafik (4), } \\
\text { diğer (5) }\end{array}$ & $\begin{array}{l}\text { aile (21), sosyal ilişkiler (8), cinsiyet (4), } \\
\text { topluluk (6), hastalığa dayalı (6), gelişim } \\
\text { dönemi (3), eğitim- öğretim (2), diğger (6) }\end{array}$ \\
\hline & 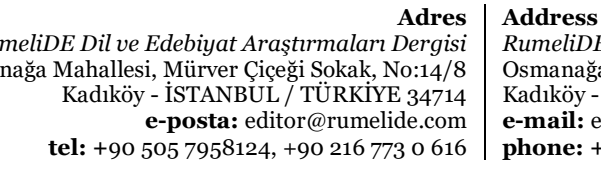 & $\begin{array}{l}\text { Journal of Language and Literature Studies } \\
\text { Mahallesi, Mürver Çiçeği Sokak, No:14/8 } \\
\text { ISTANBUL / TURKEY } 34714 \\
\text { litor@rumelide.com, } \\
\text { 90 505 7958124, +90 } 216773 \text { o } 616\end{array}$ \\
\hline
\end{tabular}




\begin{tabular}{|c|c|c|}
\hline & Toplam: 6o kavram & Toplam: 56 kavram \\
\hline \multirow[t]{2}{*}{ Nicelik (5-5) } & $\begin{array}{l}\text { net sayısal karşılığı olan (39), belirsizlik } \\
\text { içeren (31), para (17), ölçü birimi (23), } \\
\text { yüzdelik oranlar (1) }\end{array}$ & $\begin{array}{l}\text { net sayısal karşılığı olan ( } 76 \text { ), belirsizlik } \\
\text { içeren (32), para (9), ölçü birimi (17), } \\
\text { yüzdelik oranlar (6) }\end{array}$ \\
\hline & Toplam: 111 kavram & Toplam: 140 kavram \\
\hline \multirow[t]{2}{*}{ Konum (4- 4) } & $\begin{array}{l}\text { iç- ara (6), üst- alt (3), ön- arka- geri (6), } \\
\text { kenar (2) }\end{array}$ & $\begin{array}{l}\text { iç- ara (3), üst- alt (5), ön- arka- geri (4), } \\
\text { kenar (5) }\end{array}$ \\
\hline & Toplam: 17 kavram & Toplam: 17 kavram \\
\hline \multirow[t]{2}{*}{ Parça (3- 2) } & teknolojik alet (4), taşıt (4), diğer (3) & teknolojik alet (4), diğer (2) \\
\hline & Toplam: 11 kavram & Toplam: 6 kavram \\
\hline \multirow[t]{2}{*}{ Zaman (9-12) } & $\begin{array}{l}\text { yıl (18), saat (15), ay (9), gün aralıkları (15), } \\
\text { gün (14), belirsizlik (53), dönem (7), insan } \\
\text { hayatı (13), diğer (11) }\end{array}$ & $\begin{array}{l}\text { yıl (79), mevsim adları (3), hafta (3), saat (9), } \\
\text { ay (6), gün aralıkları (6), gün (8), belirsizlik } \\
\text { (52), spor karşılaşmaları (18), dönem (13), } \\
\text { insan hayatı (17), diğer (11) }\end{array}$ \\
\hline & Toplam: 155 kavram & Toplam: 225 kavram \\
\hline \multirow[t]{2}{*}{ Biliş (2- 3) } & bilgi (5), diğer (1) & bilgi (5), hayal (3), diğer (3) \\
\hline & Toplam: 6 kavram & Toplam: 11 kavram \\
\hline \multirow[t]{2}{*}{ Nitelik (3-3) } & $\begin{array}{l}\text { niteleme (248), karşılaştırma yapıları (2), } \\
\text { renk adları (2) }\end{array}$ & $\begin{array}{l}\text { niteleme (215), karşılaştırma yapıları (2), } \\
\text { renk adları (1) }\end{array}$ \\
\hline & Toplam: 252 kavram & Toplam: 218 kavram \\
\hline Diğer (1- 1) & 157 & 138 \\
\hline Toplam & 1665 & 1812 \\
\hline
\end{tabular}

Tablo 4'e göre 29 kavram alanı oluştuğu görülmektedir. Herhangi bir kavram alanına dahil edilemeyen kavramlar diğer bölümüne aktarılmıştır.

Tablo 4'e bakıldığında Türkçeye Yolculuk ders kitabında en çok ulamın yer aldığı kavram alanı yer (13) iken Altay Türkçe Öğreniyorum ders kitabında da en fazla ulamın yer aldığı kavram alanı yer (15) olmuştur. Yani iki kitapta da yer kavram alanına ait ulamların sayısı en yüksektir. Türkçeye Yolculuk ders kitabında en fazla kavram sayısına sahip olan kavram alanı nitelik (252) iken, Altay Türkçe Öğreniyorum ders kitabında zaman (225) olmuştur.

Tablo 4'e göre Türkçeye Yolculuk ders kitabında en az ulam sayısına sahip olan kavram alanı oluş (1), bitki (1) ve enerji (1) iken Altay Türkçe Öğreniyorum ders kitabında oluş (1) kavram alanıdır. Yani her iki ders kitabında da oluş kavram alanında da bir ulama ulaşılmıştır. Türkçeye Yolculuk ders kitabında en az kavram sayısına sahip kavram alanı bitki (2) iken Altay Türkçe Öğreniyorum ders kitabında oluş (4) ve enerji (4) olmuştur.

\section{Sonuç ve öneriler}

Ders kitaplarının incelenmesi sonucunda ulaşlan 29 kavram alanı şunlardır: Hayvanlar, eğitim, oluş, bitki, oyun, dil, durum, ulaşım, enerji, yer, vücut, yiyecek, duygular, sağlık, duyu, doğa, ediş, iletişim, kültür, sanat, meslek, eşya, insan, nicelik, konum, parça, zaman, biliş, niteliktir. Herhangi bir kavram

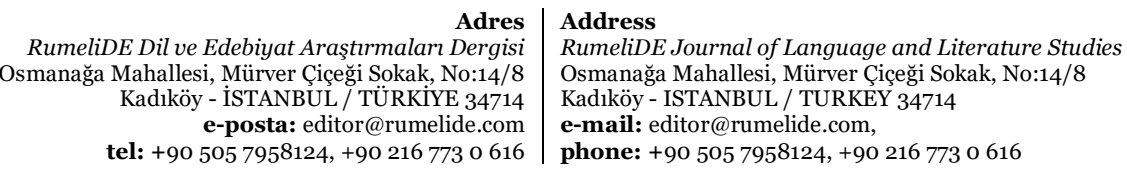


alanı içerisinde yer almayan kavramlar ise diğer olarak adlandırılmıştır. İki ders kitabında da kavram alanı sayısı eşittir. Bu, sınıflandırma mantı̆̆ı, ünite ve bağlam çerçevesinde kabul edilebilir bir durumdur.

Çalışmamıza konu olan ders kitaplarındaki kavramların içerik analizi ile çözümlenmesi sonucunda Altay Türkçe Öğreniyorum B1 ders kitabında 155 ulam, Türkçeye Yolculuk B1 ders kitabında 144 ulam belirlenmiştir. Bir başka deyişle Altay Türkçe Öğreniyorum B1 ders kitabındaki ulam sayısı, Türkçeye Yolculuk B1 ders kitabındaki ulam sayısından fazladır. Altay Türkçe Öğreniyorum B1 ders kitabındaki kavram sayısı 1812, Türkçeye Yolculuk B1 ders kitabındaki kavram sayısı 1665’tir. Diğer bir ifadeyle Altay Türkçe Öğreniyorum B1 ders kitabındaki kavram sayısı Türkçeye Yolculuk B1 ders kitabındaki kavram sayısından fazladır. Hem ulam hem de kavram sayısı bakımından Altay Türkçe Öğreniyorum B1 ders kitabı, Türkçeye Yolculuk B1 ders kitabından fazla olduğu görülmektedir. İnceleme sonucunda ulam çeşitliliği ve sayısı bakımından iki kitap da görece yeterlidir.

Yabancı dil olarak Türkçe öğretimi alanında bu araştırmaya benzer yapıda bir çalışma bulunamadığı için karşılaştırma açısından bir tartışma yapılamamıştır.

$\mathrm{Bu}$ çalışmada elde edilen bulgulara göre bazı kavram alanlarındaki kavram sayısının az olduğu görülmüsstür. Bu alanda ders kitabı hazırlayanlara, her ulamdan kavram çeşitliliğine dikkat ederek metinleri seçmesi önerilebilir. Ayrıca etkinlikler tasarlanırken ders kitabındaki temaya uygun kelime ve kavram etkinliklerine yer verilmelidir. Tema sonunda temel düzey ile ilişkili kavramların listesi verilmelidir. Öğrenicilerin kavramları zengin bir şekilde edinmeleri ve başka anlamlarda kullanabilmeleri için bir kavram alanına ait kavramlarla ilişkilendirerek metinler düzenlenmelidir. Kitap hazırlayıcıları her ünite için bu çalışmadaki gibi bir sınıflandırma yapabilir. Böylece öğreticilere veya öğrenicilere verilecek kavram ve kelime listesi ortaya çıkmış olur. Metin işleme sırasında bağlama göre bu liste işlevsel bir şekilde kullanılabilir. Öğretici ders ortamında bir metni işlerken ilgili ulamdaki kavramların bağlantılarını verebilir. Kelime ve kavramların işaret ettiği, öğrenme ortamında bulunan varlık veya nesneleri gösterip kullanabilir, olmayanların görselleri üzerinde durabilir. Böylece kelime öğretimi hızlı ve yapılandırıcı biçimde gerçekleşebilir.

Bu çalışmada B1 düzeyindeki kavramlar tespit edilmiştir. Yabancı dil olarak Türkçenin öğretimi alanında yapılacak araştırmalarda diğer düzeyler için hazırlanan kitaplardaki kavram alanları tespit edilmelidir. Böylece her düzey için kavram alanı, ulam ve kavram listesi ortaya çıabilir. Dolayısıyla hem kitap hazırlayıcılara hem de öğreticilere hangi düzeyde hangi kavramların öğretilmesi gerektiği ortaya konabilir. Tekrarlı çalışmalarla geniş bir havuza ulaşıldığında hiyerarşik biçimde hangi kavramlara ait hangi kelimelerin öğretileceğine karar verilebilir. $\mathrm{Bu}$ yapının kurulmasında kelime sıklı̆̆ çalışmalarından da yararlanılabilir. Böylece gelecekteki çalışmalarda öğrenicilerin katılımı da sağlanıp bu yapının geçerliği sınanabilir.

\section{Kaynakça}

Akyürek, S. (2003). Din öğretiminde kavram öğretimi. (Yayımlanmamış doktora tezi). Erciyes Üniversitesi Sosyal Bilimler Enstitüsü, Kayseri.

Arı, G. (2014). Kelime öğretimi. Cemal Yıldız (Ed.). Yeni öğretim programına göre kuramdan uygulamaya Türkçe öğretimi içinde. (311- 333 ss.). Ankara: Pegem.

Aşık, G. (2020). Yabancılar için hazırlanan Türkçe ders kitaplarındaki kavramlar ve kavram alanları: Yeni Hitit örneği. (Yayınlanmamış yüksek lisans tezi). Ankara Üniversitesi Sosyal Bilimler Enstitüsü, Ankara.

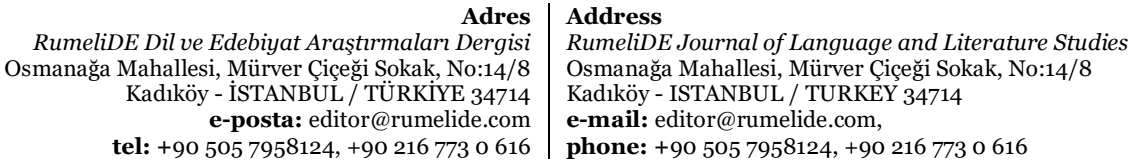


Borghi, A. M., Caramelli, N., \& Setti, A., (2005). Conceptual information on objects' locations. Brain and Language, 93, 140-151. doi:10.1016/j.bandl.2004.09.004

Cevizci, A. (1999). Felsefe sözlüğü. İstanbul: Paradigma.

Coşkun, Ö. (2006). İlköğretim 2. ve 3. simf ders kitaplarmda kavramlar ve kavram alanları. (Yayınlanmamış yüksek lisans tezi). Ankara Üniversitesi Sosyal Bilimler Enstitüsü, Ankara.

Çengelci, N. B.(1996). Gelişimsel olarak kavram ve kategori yapılarının incelenmesi. (Yayınlanmamış doktora tezi). Ege Üniversitesi Sosyal Bilimler Enstitüsü, Ankara.

Develi, H., Yıldız, C., Karadoğan A., Balcı, M., Gültekin, İ., Melanlığlu, D., Okur, A. (Ed.). (2017). Türkçeye yolculuk b1 ders kitabı. Ankara: Kesit.

Eken, N. T. (2015). Çocuklar için hazırlanan öykü kitaplarındaki kavramlar ve kavram alanları. İternational Journal of Langues' Education and Teaching, 3(1), 392- 413.

Gunina, N. (2011). Concept vs meaining: Cognitive aprroach. Transactions of the TSTU 17(1), 248-250.

Kalfa, M., Karadağ, Ö. (Ed.). (2018). Altay Türkçe öğreniyorum b1 ders kitabı. Ankara: Korza.

Karadă̆, Ö. (2013). Kelime öğretimi. Ankara: Kriter.

Koç, N. (1996). Yeni dilbilgisi. İstanbul: İnkılap.

Löbner, S. (2002). Understanding semantics. New York: Oxford University Press Inc.

Onan, B. (2011). Anlama sürecinde Türkçenin yapısal işlevleri. Ankara: Nobel Akademik Yayıncılık ve Eğitim Danışmanlık.

Pesonen, J. P., (2002). Concepts and object-oriented knowledge representation. (MA Thesis) University of Helsinki Department of Cognitive Science, Helsinki.

Ülgen, G. (2001). Kavram geliştirme, kuramlar ve uygulamalar. Ankara: Pegem.

RumeliDE Dil ve Edebiyat Araştırmaları Dergisi Osmanağa Mahallesi, Mürver Çiçeği Sokak, No:14/8 Kadıköy - İSTANBUL / TÜRKIYE 34714 e-posta: editor@rumelide.com tel: +90 $5057958124,+902167730616$
Address

RumeliDE Journal of Language and Literature Studies Osmanağa Mahallesi, Mürver Çiçeği Sokak, No:14/8

Kadıköy - ISTANBUL / TURKEY 34714

e-mail: editor@rumelide.com,

phone: +90 $5057958124,+902167730616$ 